\title{
Environmental, Social and Governance (ESG) Evaluation and Organizational Attractiveness to Prospective Employees: Evidence From Japan
}

\author{
Lian Liu \\ Asian Development Bank Institute \\ Naoko Nemoto \\ Waseda Business School
}

This study hypothesized that firms' Environmental, Social and Governance (ESG) evaluation is related positively to their attractiveness to prospective employees. Although growing number of researches have been focusing on relations between ESG evaluation and corporate financial performance, few researches have investigated the link between ESG evaluation and corporate attractiveness as employers. Results indicate ESG evaluation is related to firms' attractiveness as employers, suggesting that a firm 's high ESG scores may provide a competitive advantage in attracting human talents and enhancing corporate value. At a time when corporate success depends on a high-level staff, the need for corporate to improve ESG evaluation is intensifying. Regarding the impact of ESG component, the study shows Environmental factor has significant positive impact on attractiveness of larger firms, while Governance is most relevant for smaller firms.

Keywords: ESG, corporate value, corporate brand

\section{INTRODUCTION}

This study tests the hypothesis that corporate with high Environmental, Social and Governance (ESG) evaluation have competitive advantages in attracting a larger pool of candidates and improving corporate value.

Recently, an increasing number of investors have incorporated non-financial factors measured by environmental, social, and governance (ESG) issues into their investment decision making (World Bank, 2018). ESG investment has expanded and reached $\$ 30.68$ trillion in the five major markets in 2018, increasing from \$ 18.23 trillion in 2014 (Global Sustainable Investment Alliance, 2018). Since COVID-19 shock in early 2020, the inflow of funds into ESG investment has further accelerated (IIF, 2020) ${ }^{1}$. Reasons for the increase in investment balance are as follows (Yuyama, 2020): 1) implementation of Principal of Responsible Investment ${ }^{2}$ under the leadership of the United Nations, which has been supported by more than 3,000 investors, 2) the adoption of the Sustainable Development Goals by 193 member countries of United Nations in 2015 and subsequent policy responses, 3) increased awareness of climate change risks in the wake of the Paris Agreement (2015) and other factors, and 4) increased interest in unemployment, economic inequality, and sustainable growth of companies due to pandemic risks. When factoring into ESG investments, investors often refer to the scoring of ESG evaluation companies and regard their assessment 
as benchmark. Morgan Stanley Capital International (MSCI) ${ }^{3}$, FTSE Russell ${ }^{4}$, and Sustainalytics ${ }^{5}$ are known as market leaders (World Bank, 2018).

A similar concept to ESG evaluation is Corporate Social Performance (CSP), which represents a company's efforts in line with the Corporate Social Responsibility (CSR). CSR comprises a company's discretionary multi-dimensional activities related to social, environmental, ethical, and economic performance of the business (McWilliams et al., 2006). The concept of CSR has a quite long and vast literature (Mosca \& Civera, 2017). ESG factors are chosen to evaluate a company's CSR-based behavior from the perspective of investment decisions.

As majority of ESG investment expects monetary returns as well as social returns, increasing number of empirical researches have explored the link between ESG evaluation and corporate financial performance. The results are inconclusive, while $60 \%$ of existing literature shows there is positive link between ESG evaluation and corporate financial performance (Friede et al., 2015). One reason for the continued debate relates to the variety of methodologies in which ESG factors are evaluated (Suto and Takehara 2016). In addition, limited research has been conducted to further explicate the transmission channels between ESG evaluation and corporate financial performance (Yuyama, 2020).

To date, some researches have shed the light on how ESG factors are linked to corporate' competitive advantage and long-term corporate values (Brammer and Pavelin, 2006; Hur, Kim and Woo, 2013; Melo and Garrido-Morgado, 2012). Ibuki (2003) points out that corporate CSR initiatives not only reduce corporate risk, but also improve their competitive position. As examples of concrete effect, "superiority in transaction, improvement of employee loyalty, improvement of enterprise brand value" are named.

Perception of corporate managers and investors are divided on whether ESG initiatives will create economic value. According to a McKinsey's survey targeting top corporate managers and investors, those who agreed that ESG factors contribute to increased corporate value was $57 \%$ in 2019 , showing small increase from 54\% in 2009 (McKinsey, 2020).

Given inconclusiveness of existing literature, market perception and limited analysis to explore the linkage of ESG and corporate value, the relations between ESG and corporate attractiveness as employer represents an interesting research theme. Attracting and retaining superior human resources can provide organization with a competitive advantage and sustainable growth (Hiller and Kroll, 1995).

The study shows ESG evaluation is related to firms' attractiveness to potential employee, suggesting that a firm's high ESG scores may provide a competitive advantage in attracting human talents and enhancing corporate value. This result is supported by the existing theories, namely signaling theory and social identity theory. Prior literature suggested that because applicants have incomplete information about organization, they interpret ESG information they receive as signals about the organizations' working conditions and sustainable management (Fisman et. al 2006). Additionally, social identity theory suggests that people classify themselves into social categories based on various factors such as the organization they work for, and that membership in these social categories influences an individual's self-concept (Dutton et. Al., 1994).

The empirical analysis is based on panel regression models with a data set of the top 300 companies in Japan in terms of market capitalization during 2016-2019. As a proxy of attractiveness as employers, we use Employment Brand Ranking based on the survey targeting university and graduate school students who are hunting for jobs. Regarding ESG evaluation, we use CSR scoring of Toyo Keizai, which is widely used in Japan. The study divides the target companies in two groups in terms of market capitalization and applies the model to each group. The coefficient significance of each component is different depending on the group of firms. E(environment) factor has significant positive impact on attractiveness for employer in the group of firms with larger size, while G(governance) has significant impact in the group of firms with smaller size.

In Japan, the penetration of ESG investment is lagging that of Europe and the United States, but the recent increase is remarkable. The amount outstanding of ESG investment has increased 2.5-times in two years from Y 137 trillion in 2017 to Y 336 trillion in $2019^{6}$. On the other hand, there is still little empirical research on the effectiveness of ESG investment, especially link between ESG evaluation and corporate value. Some corporate managers and investors hold cautious views toward ESG investment ${ }^{7}$ as they believe 
the effectiveness of ESG investments has not been fully verified. The results of this study have implications for the strategies of corporate management and policy makers. Improving ESG evaluation will support the organizations to appeal to potential employee and secure sustainable growth. The findings could also be useful for investors who adopt ESG factors in decision making.

This study aims to contribute to the previous literature in four aspects. First, it presents an analysis of linkage between ESG evaluation and attractiveness for potential applicants in Japan, which has not been verified by previous research. Second, compared to previous research (Turban and Greening, 1997), the data sample has been expanded, and more variables that may affect the attractiveness of companies are factored in the model. Third, this study shows mechanism that higher ESG evaluation can attract high quality human resources and potentially improve corporate value. Fourth, it analyzes which ESG component has a significant impact on corporate attractiveness.

The remainder of this study is structured as follows. Section 2 reviews the relevant literature and discusses research hypothesis. Section 3 explains the data and the methodology. Section 4 presents the empirical results and the robustness check. Finally, Section 5 discusses implications for the development of ESG investment and provide avenues for future research.

\section{RELATED LITERATURE AND RESEARCH HYPOTHESIS}

\section{The Relationship Between ESG Performance and Financial Performance}

ESG investment has attracted a growing interest from research scholars over the past decades. Most of those studies have focused on analyzing the relation between ESG and corporate financial performance (Suto and Takehara, 2016; Zhao et al., 2018; Su et al., 2010; Beck et al., 2018). Majority of the results identify positive correlation, though some are insignificant or negative (Margolis and Walsh, 2003; Van Beurden and Gossling, 2008). Based on the research of Margolis and Walsh (2003), which reviews 127 studies between 1972 and 2002, the relationship between ESG and financial performance could be positive (109 studies), negative (seven studies), or insignificant (28 studies). Friede et al. (2015) reviewed more than 2,200 existing researches and found $60 \%$ of literature related with corporate equity shows there is positive link between ESG evaluation and corporate financial performance.

In Japan, less empirical researches have been conducted on this issue and results are mixed. Yuyama et al. (2019) investigated the link between stock price returns and ESG disclosure scores of Japanese firms, which shows no significant relations between two factors excepting the results in 2017. Suto and Takehara (2016) identified that higher Corporate Social Performance is related with lower market-based risk measures of Japanese firms such as historical volatility of stock returns, while the effects of CFP on firm's profitability is mixed.

One reason for the continued debate relates to the variety of methodologies in which ESG factors are evaluated (Suto and Takehara, 2016). In addition, the results depend on specific situation and time horizons (Yuyama, 2020). ESG activities may have a positive association with financial performance in certain environments, but a negative association or no association in other environments (Carroll and Shabana, 2010). Besides, ESG activities often involve a long-term process and take years to fully develop and pay off financially. Yet most related researches are based on a short time horizon, which may contribute the mixed results. Brammer and Millington (2008) investigate the link of corporate social performance (CSP) and corporate financial performance (CFP) and claimed that the firms with both unusually high and low CSP have higher financial performance than other firms, with unusually poor social performers doing best in the short run and unusually good social performers doing best over longer time. In support of their arguments, they present the empirical model and collection the data of from 537 firms' annual reports that registered in the London Stock Exchange in 1999.

\section{Mechanism and Channels to Link Between ESG Evaluation and Financial Performance}

The transmission channels that link ESG evaluation with corporate financial performance remain to be debated. Prior literature explained the linkage based on the stake holder's theory. Jensen (2001) indicates companies with high ESG evaluation have advantage in strategic management of various stakeholders, 
which is a vital component for the efficient creation of long-term firm value. A strand of literature (Gregory et al., 2014) argues that companies with a strong ESG profile establish competitive edge due to the more efficient use of resources, or better innovation management, which help generate abnormal returns and ultimately leads to higher corporate value. Another strand of literature (El Ghoul et al., 2011; Jo and Na, 2012; Oikonomou et al., 2012) suggests that companies with strong ESG characteristics typically have better risk management, so they suffer less from severe incidents such as fraud, embezzlement, corruption, that can adversely impact the value of the company.

\section{The Relationship Between ESG Evaluation, Corporates' Attractiveness as Employers and Corporate Brand}

Turban et.al. (1997) noted that firms engaging in CSR would have more positive reputations and would be perceived as more attractive employers by potential applicants, thereby providing those companies with a competitive advantage over their rivals. This study is based on data of 160 firms in the US. They use polls by students in the strategic management course $(n=75)$ as a proxy of attractiveness. To estimate a model of firms' attractiveness, firms' profitability and size are controlled.

Other researches have focused on analyzing the relation between ESG evaluation and non-financial values such as corporate brand. Some of them use brand fidelity and Fortune ranking as the proxy measures of corporate brand (Hoeffler and Keller, 2002; Garberg and Fombrun, 2006; Melo and Garrido-Morgado, 2012). Majority of studies reveal a positive relationship between ESG evaluation and corporate brand. Garberg and Fombrun (2006) conclude that ESG activities are stimulants for increasing brand reputation in the minds of customers, thus making it an important strategy to build corporate brand.

This paper explores mechanism where ESG evaluation could affect corporate values by influencing on corporate ability to attract and retain human talents. Another contribution of this study is that it utilizes larger and unbiased samples and incorporates recent data about when ESG investment gained momentum. The study also investigates the impact of each ESG component over corporates attractiveness.

\section{Research Hypothesis}

Based on the prior reference, this paper derives following hypotheses to detect the link between ESG evaluation, corporates attractiveness as employers and corporate value:

\section{H1: A positive relationship exists between ESG evaluation and corporates attractiveness as employers.}

This hypothesis is supported by the existing theories, namely signaling theory (Fisman et. Al 2006) and social identity theory (Dutton et.al 1994). This result is consistent with the results of existing survey. According to Deloitte's millennial survey, the millennium generation place priority to ESG factors as the purpose of business. For instance, $32 \%$ of respondents believe the business should achieve improvement of society, while $27 \%$ say the business should achieve generating profits. The survey also shows those who perceive their workplace is engaged in environmental protection and other ESG issues tend to have high motivation and loyalty to the company (Deloitte, P., 2019).

\section{H2: A positive relationship exists between corporate attractiveness as employers and corporate value.}

Attracting and retaining superior human resources can provide organization with a sustained competitive advantage and sustainable growth (Hiller and Kroll, 1995). With the current labor shortage in some sectors and the projected shortage amid aging society, attracting top-quality young applicants is becoming increasingly important for organizational success in Japan and other countries. This study verifies this hypothesis by estimating the effects of corporate attractiveness on Tobin's Q which is a proxy of corporate value. 


\section{DATA AND METHODOLOGY}

\section{Data}

Dependent Variable: Attractiveness for Employers (Employment Brand Ranking)

The data in this analysis span from 2016-2019 on a yearly basis. To test the hypothesis 1 and measure corporate attractiveness as employers, this study uses the employment brand ranking, created by the Bunka Broadcasting Career Partners Employment Information Research Institute, one of the most famous employment information companies in Japan. This institute has conducted "employment brand survey" during October and March and published the results in April and August since 2001. More than 20,000 university and graduate students who are registered on the employment information site responded. The employment ranking is made based on the result of the poll. The top 300 companies are regularly announced by its official site ${ }^{8}$ and Toyo Keizai magazines which are widely read among businesspersons. We used the survey results published in latter half of the year, as students vote after attending the firm briefings or interviews and it could be a more accurate assessment. In this research, the employment brand ranking is split into a 7-point scale, with 1 meaning that the companies are ranked 1 to 50 , while 7 meaning that the companies are ranked beyond 300 .

\section{Dependent Variable: Tobin's $Q$}

To verify the hypothesis 2, this study uses Tobin's Q ration as a proxy for corporate value based on prior literatures (Cho, 1998; Davies et al. 2005). First, Tobin's Q ratio is always considered as a long-term and forward-looking performance measure. It is in line with the attributes of ESG evaluation, that are more likely to pay off in the long run. Second, as a market-based measures, Tobin's Q ratio minimize the effects of any possible distortion in financial performance, resulting from firms' reporting incentives and accounting choices (Servaes and Tamayo, 2013; Cho and Tsang, 2020). As such, we estimate Tobin's Q ratio using the formula below:

Q ratio $_{i t}=\frac{\text { Cap }}{\text { Asset }}$

where, Cap represents market capitalization of the company, while Asset represents total assets.

\section{Independent Variable: ESG Evaluation}

To measure ESG evaluation for Japanese firms, the study uses the Toyo Keizai CSR Corporate Ranking created by Toyo Keizai. The CSR Ranking evaluates the four dimensions of corporate CSR-based behavior, namely environment, human resource utilization, social contribution, and corporate governance ${ }^{9}$. They research CSR through questionnaire surveys of companies and gives them a rating and a score out of 100 with a higher score indicating better ranking. The survey was launched in 2001 and announced once a year. The 2019 survey covered1,501 companies including 1,456 listed and 145 unlisted companies. This study chooses the CSR ranking as they have the greatest coverage of Japanese companies except for Bloomberg, have a long history of research, are infiltrating the Japanese market, and are supervised by researchers which ensures independence. The total number of firm-years for the sample is reduced to around 780 due to the lack of employment brand ranking or financial data.

It should be noted that the CSR ranking is evaluated by Toyo Keizai and is not the same as the performance of CSR or ESG. In some items, the point is added if there is disclosure of the company, and not because of the superiority or inferiority of the number.

\section{Control Variable}

Drawing on the literature that examines the drivers of corporate attractiveness and corporate brand, the control variables are corporate size (market capitalization), return on assets (ROA), revenue growth, priceto-earnings ratio $(\mathrm{P} / \mathrm{E})$ and industry classification. We use the natural logarithm of market capitalization (in millions of Japanese yen) as a proxy for firm size. Larger firms tend to be more visible to the publics and 
ordinary people could hold more information regarding the activities of larger firms, so larger firms should be expected to obtain a better reputation than smaller rivals (Brammer and Pavelin, 2006).

Strong financial performance has been widely proved to help a firm establish a good reputation, since it generally signals an effective corporate strategy, good management, and good resource allocations, and so on (Roberts and Dowling, 2002; Sabate and Puente, 2003). Revenue growth is used to capture how fast a business is expanding. ROA and $\mathrm{P} / \mathrm{E}$ ratio are used to capture corporate profitability and market-based performance, respectively. We expect positive relations between corporate size, ROA, revenue growth and corporate attractiveness.

Existing literature suggests that industry sector is a mediating player between corporate brand and ESG factors as each sector would have different industry-specific stakeholder pressures and responses on ESG strategy (Brammer and Pavelin, 2006; Melo and Garrido-Morgado, 2012). For instance, environmental performance tends to have a negative impact on reputation in certain sectors, but not in the chemicals, consumer products, resources, and transportation sectors. As such, we control industry factors using dummy based on Global Industry Classification Standards. The year dummy is included as the control variables because financial market conditions and business cycle may have impact on attractiveness of specific corporate sectors. The primary source of financial statement data is Capital IQ provide by S\&P Global.

\section{Methodology}

Using the data sets explained in Section 3.1, a twofold approach is implemented. First, we developed the following panel data regression model to estimate corporate attractiveness (corporate employment brand ranking):

Ranking $_{i t}=\alpha_{0}+\alpha_{1} E S G_{i t}+\alpha_{2} X_{i t}+\alpha_{3} \gamma_{t}+\mu_{i t}$

where, $\mathrm{i}$ and $\mathrm{t}$ denote the firms and time indices, respectively. The residuals are $\epsilon_{i t}=\gamma_{t}+\mu_{i t}$, where $\gamma_{t}$ represents the unobserved time specific effect, while $\mu_{i t}$ represents the random error term. $\alpha_{0}$ represents constant terms. Ranking it denotes employment brand ranking, as a reflection of corporate attractiveness for employer. $C S R_{i t}$ denotes corporate CSR ranking. The variable is lagged by 4 months to mitigate against endogeneity concerns. To examine the impact of different aspects of ESG (Environment, human resource utilization, social contribution, and corporate governance) on corporate attractiveness, we estimate separate models by replacing $C S R_{i t}$ with $E_{i t}, S 1_{i t}, S 2_{i t}, G_{i t}$, respectively. Here, $E_{i t}$ denotes environment. $S 1_{i t}$ denotes human resource utilization. $S 2_{i t}$ denotes social contribution. $G_{i t}$ stands for corporate governance.

$X_{i t}$ is a vector of control variables for equation (2). Our primary control variables in our model are market capitalization, return on assets (ROA), revenue growth, price-to-earnings ratio (P/E), and industry dummy.

Second, we developed the following regression model to explore the link between corporate value and corporates' attractiveness as employers.

ratio $_{i t}=\alpha_{0}+\alpha_{1}$ Ranking $_{i t}+\alpha_{2} Y_{i t}+\alpha_{3} \gamma_{t}+\mu_{i t}$

Q $_{\text {ratio }_{i t}}$ denotes Tobin's Q ratio. CSR $R_{i t}$ denotes corporate CSR ranking. Ranking it $_{\text {represents }}$ employment brand ranking, as a reflection of corporates' attractiveness for employer. $Y_{i t}$ is an array of control variables for equation (3), which comprise total asset, financial leverage measured by corporate debt as a percentage of equity, ROA, revenue growth rate and industry dummy?

First, company size is widely recognized as an essential factor affecting corporate financial performance because larger firms have greater bargaining power over suppliers and buyers, and thus could positively affect corporate value (Waddock and Graves, 1997; Cho and Tsang, 2020). Second, financial leverage is one of tools a company can use to make the best financing and investment decisions. Stable and optimal capital structure contributes to better financial performance. Therefore, we include it as the control variable. Third, sales growth rate represents growth potential of firm. Finally, ROA is included in the regression model to control the effect of firms' current profitability. 


\section{Descriptive Statistics and Correlation of Variables}

Table 1 reports the descriptive statistics of main variables employed in this study. The corporate ESG scores range from 20 to 100 points.

TABLE 1

DESCRIPTIVE STATISTICS

\begin{tabular}{|c|c|c|c|c|c|c|}
\hline & Obs. & Mean & Median & Std. Dev. & Min & Max \\
\hline Ranking $^{a}$ & 1056 & 4.381 & 5 & 2.201 & 1 & 7 \\
\hline Q Ratio $^{\mathrm{b}}$ & 1032 & 0.888 & 0.545 & 0.969 & 0 & 9.359 \\
\hline $\mathrm{ESG}^{\mathrm{c}}$ & 703 & 75.513 & 87.65 & 12.672 & 20 & 100 \\
\hline$E^{c}$ & 749 & 83.555 & 87.7 & 13.099 & 20 & 100 \\
\hline $\mathrm{S} 1^{\mathrm{c}}$ & 781 & 82.992 & 84.5 & 10.441 & 20 & 100 \\
\hline $\mathrm{S} 2^{\mathrm{c}}$ & 791 & 81.635 & 85.2 & 13.067 & 20 & 100 \\
\hline $\mathrm{G}^{\mathrm{c}}$ & 755 & 90.119 & 92.7 & 8.279 & 20 & 100 \\
\hline $\operatorname{Ln}(\text { cap })^{d}$ & 1042 & 13.244 & 13.367 & 1.587 & 3.802 & 16.883 \\
\hline $\operatorname{Ln}(\text { asset })^{\mathrm{e}}$ & 1041 & 13.863 & 13.688 & 1.890 & 3.753 & 20.138 \\
\hline $\mathrm{ROA}^{\mathrm{f}}$ & 913 & 5.203 & 4.5 & 4.075 & -28.479 & 21.580 \\
\hline $\operatorname{Debt}^{\mathrm{g}}$ & 1042 & 0.875 & 0.372 & 2.062 & -0.270 & 28.285 \\
\hline $\mathrm{P} / \mathrm{E}^{\mathrm{h}}$ & 973 & 22.534 & 16.844 & 20.940 & 3.500 & 218.594 \\
\hline Growth $^{\mathrm{i}}$ & 1024 & 3.299 & 2.522 & 10.287 & -35.034 & 115.844 \\
\hline
\end{tabular}

Note: ${ }^{a}$ Employment ranking

b Tobin's Q ratio

${ }^{c}$ ESG aggregate score; E, S1, S2 and G represent environmental, human resource utilization, social and governance scores, respectively.

d Market capitalization

e Total asset

${ }^{\mathrm{f}}$ Return on asset

${ }^{g}$ Corporate debt as a ratio of corporate equity

${ }^{\text {h}}$ Price-to-Earnings Ratio

${ }^{\mathrm{j}}$ Yearly revenue growth

Table 2 displays Pearson correlations between the main variables. As expected, ESG evaluation scores provide initial evidence on the negative implication of ESG on corporate attractiveness as employers. Based on the Pearson correlation coefficients matrix, most of the correlation are less than 0.5 which offers evidence that our estimate will not suffer from multicollinearity. However, each component of ESG and ESG aggregate score show higher correlation. 


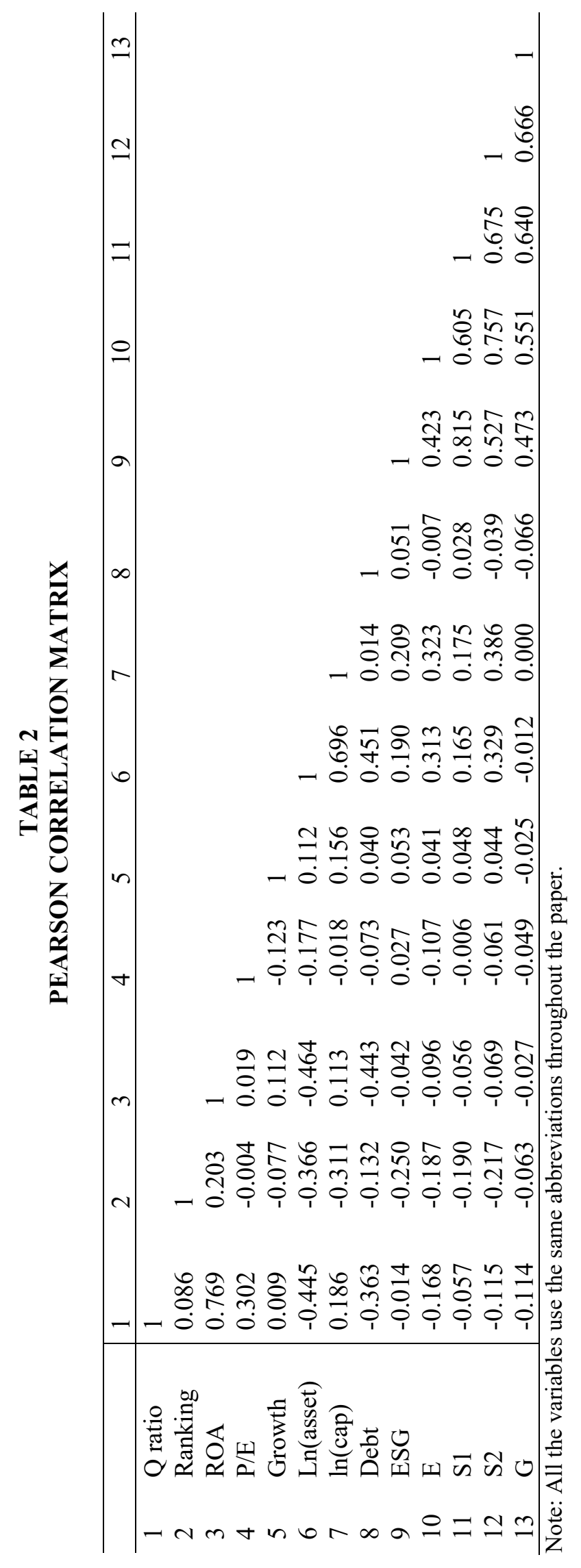




\section{EMPIRICAL RESULTS}

\section{Empirical Results}

The results from the estimation of equation (2) are provided in Table 3. The overall evaluation of ESG has significant negative signs, which suggests that higher ESG evaluation is associated with higher student brand ranking, namely higher attractiveness as employers.

To assess the effect of each ESG component, we replace the overall ESG scores with E(environment), S1(human resource utilization), S2(social contribution), and G (corporate governance). All components have significant negative signs, suggesting each component is associated with attractiveness as employers. It shows corporate with high Environmental, Social and Governance (ESG) evaluation have competitive advantages in attracting a larger pool of candidates. The result is striking in two ways. First, ESG evaluation seem to have more significant impact on organizational attractiveness than other financial indicators including revenue growth and $\mathrm{P} / \mathrm{E}$ ratio. Second, coefficient of $\mathrm{E}$ (environment) is significant with higher confidence level, compared to that of S1(human resource utilization). This is contrary to expectations that work-life balance, wages and leave systems are more essential factors in choosing the workplace. Our findings suggest potential applicants place emphasis on evaluation of corporate commitment to environmental protection, conserving and managing resources, good relations with society and fair and transparent management when choosing the firm.

The coefficients of the control variables accord largely with prior studies and are also in alignment with the findings in the related literature. To conserve space, the table does not include the coefficients associated with the time dummies and industry dummies.

Responding to Endogeneity Issue

In general, analysis of the relationship between a company's attractiveness and ESG evaluation may cause endogeneity issues. Companies with popularity among students have good name recognition and good profit margins. These factors are associated with higher capital expenditures to improve ESG factors. In order to alleviate the problem of endogeneity, we applied one- year lagged value of ESG evaluation as an instrument. In addition, we applied a fixed effect model for removing enterprise-specific factors which potentially affect a dependent variable. The Table 4 is the results of this analysis. The overall evaluation of ESG has significant negative signs, which suggests that higher ESG evaluation is associated with higher student brand ranking using the fixed effect model. As for the effect of each component, E(environment), $\mathrm{S} 1$ (human resource utilization) have significant negative signs, suggesting $\mathrm{E}$ and $\mathrm{S} 1$ are associated with student's popularity.

\section{Results of Subgroups}

We applied the model to subgroups which are divided based on the market capitalization. The coefficient significance of each component is different depending on the group. For the group of larger firms, environment has significant impact on corporate attractiveness as employer, while for the group of smaller firms, governance is significant. The prior literature indicates the corporate governance is the most critical factor affecting corporate value in Japan (Kato, 2000). Companies with weak corporate governance tend to cause serious scandals and misconducts which lead to a significant decline in corporate value (GPIF, 2018). Smaller companies have relatively insufficient resources and internal architecture to develop corporate governance, and prospective employee is expected to value governance assessments that mostly affect corporate value. On the other hand, for larger companies, it is interpreted environmental factor is more important under the assumption that the governance system is in place to some extent. 
TABLE 3

OLS REGRESSION RESULTS ON ATTRACTIVENESS FOR EMPLOYEES

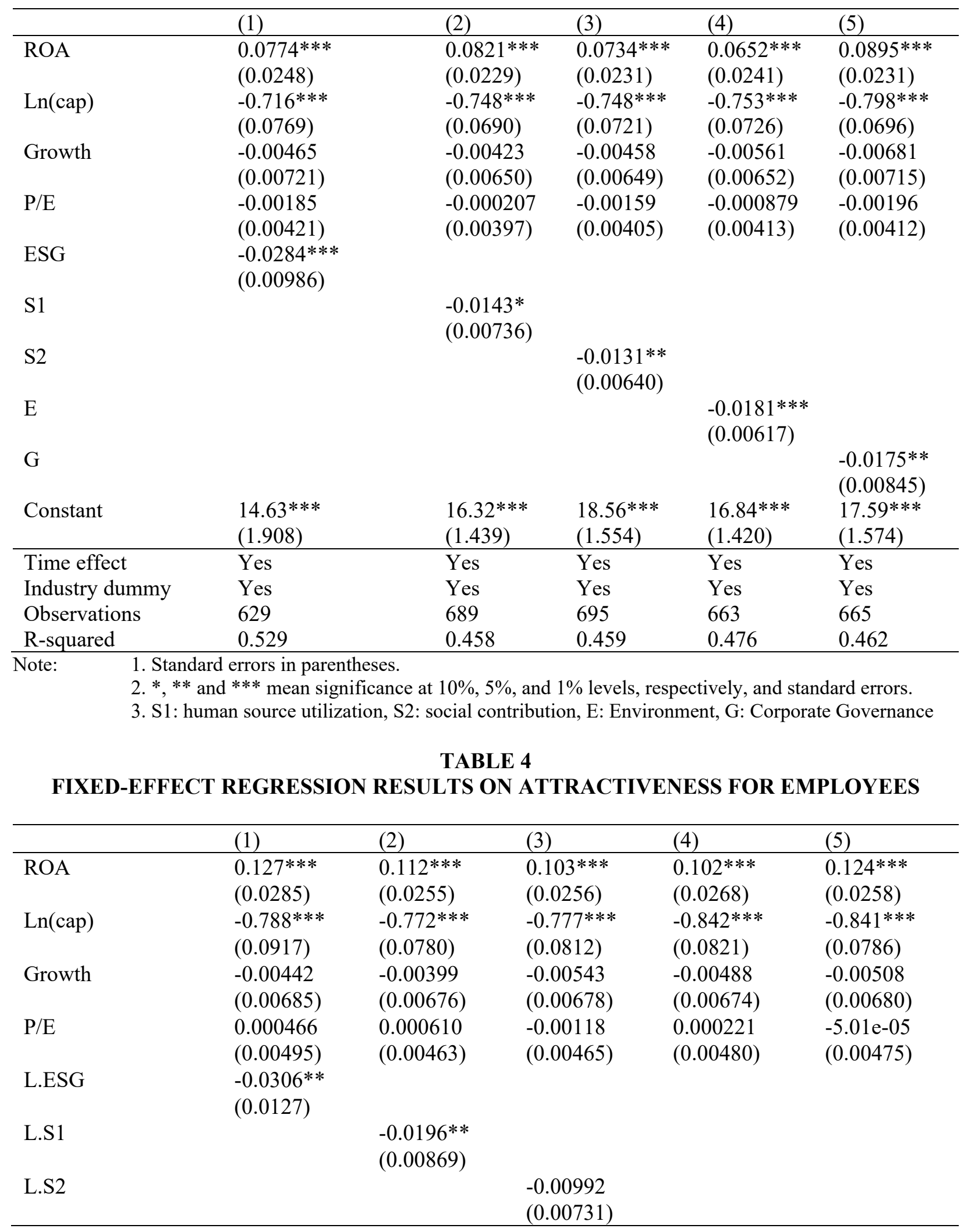




\begin{tabular}{llllll}
\hline L.E & & & & $-0.0186^{* * *}$ \\
& & & & $(0.00719)$ & \\
L.G & & & & -0.0102 \\
& & & & & $(0.00982)$ \\
Constant & $18.16^{* * *}$ & $16.52^{* * *}$ & $18.23^{* * *}$ & $17.44^{* * *}$ & $19.17^{* * *}$ \\
& $(1.785)$ & $(1.638)$ & $(1.600)$ & $(1.580)$ & $(1.828)$ \\
\hline Time effect & Yes & Yes & Yes & Yes & Yes \\
Industry dummy & Yes & Yes & Yes & Yes & Yes \\
Observations & 470 & 520 & 525 & 499 & 503 \\
R-squared & 0.513 & 0.497 & 0.492 & 0.520 & 0.494 \\
\hline Nes & & & & \\
\hline
\end{tabular}

Note: $\quad$ 1. Standard errors in parentheses.

2. *, $* *$ and $* * *$ mean significance at $10 \%, 5 \%$, and $1 \%$ levels, respectively, and standard errors.

TABLE 5

FIXED-EFFECT REGRESSION RESULTS ON ATTRACTIVENESS FOR EMPLOYEES (LARGER GROUP)

\begin{tabular}{|c|c|c|c|c|c|}
\hline & (1) & (2) & (3) & (4) & (5) \\
\hline \multirow[t]{2}{*}{ ROA } & $0.135 * * *$ & $0.117 * * *$ & $0.105 * * *$ & $0.119 * * *$ & $0.144 * * *$ \\
\hline & $(0.0327)$ & $(0.0311)$ & $(0.0307)$ & $(0.0303)$ & $(0.0305)$ \\
\hline \multirow[t]{2}{*}{$\operatorname{Ln}($ cap) } & $-0.970 * * *$ & $-0.911 * * *$ & $-0.936 * * *$ & $-1.025 * * *$ & $-1.001 * * *$ \\
\hline & $(0.189)$ & $(0.180)$ & $(0.173)$ & $(0.171)$ & $(0.179)$ \\
\hline \multirow[t]{2}{*}{ Growth } & 0.00231 & 0.000611 & $8.58 \mathrm{e}-05$ & 0.00177 & -0.00252 \\
\hline & (0.00789) & $(0.00717)$ & $(0.00701)$ & (0.00699) & (0.00719) \\
\hline \multirow[t]{2}{*}{$\mathrm{P} / \mathrm{E}$} & -0.00125 & -0.000336 & -0.00187 & -0.00350 & -0.000403 \\
\hline & $(0.00725)$ & $(0.00709)$ & $(0.00680)$ & $(0.00694)$ & $(0.00682)$ \\
\hline \multirow[t]{2}{*}{ L.ESG } & -0.0394 & & & & \\
\hline & $(0.0247)$ & & & & \\
\hline \multirow[t]{2}{*}{ L.S1 } & & -0.0119 & & & \\
\hline & & $(0.0160)$ & & & \\
\hline \multirow[t]{2}{*}{ L.S2 } & & & -0.0146 & & \\
\hline & & & $(0.0109)$ & & \\
\hline \multirow[t]{2}{*}{ L.E } & & & & $-0.0199 *$ & \\
\hline & & & & $(0.0104)$ & \\
\hline \multirow[t]{2}{*}{ L.G } & & & & & 0.0118 \\
\hline & & & & & $(0.0122)$ \\
\hline \multirow[t]{2}{*}{ Constant } & $16.91 * * *$ & $20.51 * * *$ & $21.26 * * *$ & $23.02 * * *$ & $19.89 * * *$ \\
\hline & $(3.348)$ & $(2.996)$ & $(2.924)$ & $(2.889)$ & $(3.155)$ \\
\hline Time effect & Yes & Yes & Yes & Yes & Yes \\
\hline Industry dummy & Yes & Yes & Yes & Yes & Yes \\
\hline Observations & 250 & 263 & 268 & 264 & 258 \\
\hline R-squared & 0.636 & 0.617 & 0.623 & 0.640 & 0.631 \\
\hline
\end{tabular}

Note: 1. Standard errors in parentheses.

2. *,** and *** mean significance at $10 \%, 5 \%$, and $1 \%$ levels, respectively, and standard errors. 
TABLE 6

FIXED-EFFECT REGRESSION RESULTS ON ATTRACTIVENESS FOR EMPLOYEES (SMALLER GROUP)

\begin{tabular}{|c|c|c|c|c|c|}
\hline & (1) & (2) & (3) & (4) & $(5)$ \\
\hline ROA & $\begin{array}{l}0.115^{* *} \\
(0.0524)\end{array}$ & $\begin{array}{l}0.105 * * \\
(0.0434)\end{array}$ & $\begin{array}{l}0.0929 * * \\
(0.0444)\end{array}$ & $\begin{array}{l}0.0826 \\
(0.0503)\end{array}$ & $\begin{array}{l}0.116 * * * \\
(0.0442)\end{array}$ \\
\hline Ln(cap) & $\begin{array}{l}-0.774 * * * \\
(0.234)\end{array}$ & $\begin{array}{l}-0.600^{* * * *} \\
(0.197)\end{array}$ & $\begin{array}{l}-0.638^{* * *} \\
(0.209)\end{array}$ & $\begin{array}{l}-0.766^{* * *} \\
(0.218)\end{array}$ & $\begin{array}{l}-0.692 * * * \\
(0.202)\end{array}$ \\
\hline Growth & $\begin{array}{l}-0.0283 \\
(0.0191)\end{array}$ & $\begin{array}{l}-0.0266 \\
(0.0176)\end{array}$ & $\begin{array}{l}-0.0245 \\
(0.0175)\end{array}$ & $\begin{array}{l}-0.0284 \\
(0.0185)\end{array}$ & $\begin{array}{l}-0.0225 \\
(0.0177)\end{array}$ \\
\hline $\mathrm{P} / \mathrm{E}$ & $\begin{array}{l}0.00126 \\
(0.00701)\end{array}$ & $\begin{array}{l}0.000425 \\
(0.00636)\end{array}$ & $\begin{array}{l}-0.00125 \\
(0.00647)\end{array}$ & $\begin{array}{l}0.00111 \\
(0.00683)\end{array}$ & $\begin{array}{l}-0.000910 \\
(0.00654)\end{array}$ \\
\hline L.ESG & $\begin{array}{l}-0.0193 \\
(0.0174)\end{array}$ & & & & \\
\hline L.S1 & & $\begin{array}{l}-0.0179 \\
(0.0115)\end{array}$ & & & \\
\hline L.S2 & & & $\begin{array}{l}-0.00588 \\
(0.0115)\end{array}$ & & \\
\hline L.E & & & & $\begin{array}{l}-0.0188 \\
(0.0117)\end{array}$ & \\
\hline L.G & & & & & $\begin{array}{l}-0.0350 * * \\
(0.0174)\end{array}$ \\
\hline Constant & $\begin{array}{l}15.28 * * * \\
(3.304)\end{array}$ & $\begin{array}{l}15.27 * * * \\
(2.859)\end{array}$ & $\begin{array}{l}14.93 * * * \\
(2.787)\end{array}$ & $\begin{array}{l}18.15^{* * *} \\
(2.967)\end{array}$ & $\begin{array}{l}17.95 * * * \\
(2.989)\end{array}$ \\
\hline Time effect & Yes & Yes & Yes & Yes & Yes \\
\hline Industry dummy & Yes & Yes & Yes & Yes & Yes \\
\hline Observations & 220 & 257 & 257 & 235 & 245 \\
\hline R-squared & 0.415 & 0.385 & 0.382 & 0.405 & 0.398 \\
\hline
\end{tabular}

Note: 1. Standard errors in parentheses.

$2 . *, * *$ and $* * *$ mean significance at $10 \%, 5 \%$, and $1 \%$ levels, respectively, and standard errors.

The result from equation (3) is provided in Table 7. It shows a significant negative relationship between Tobin's Q ratio and employment ranking, implying that attracting and retaining superior human resources can provide organization with a sustained competitive advantage and improve corporate value.

TABLE 7

OLS REGRESSION RESULTS ON CORPORATE VALUE

\begin{tabular}{ll}
\hline & Tobin's Q ratio \\
\hline ROA & $0.153^{* * *}$ \\
& $(0.00646)$ \\
Lnasset & $-0.125^{* * *}$ \\
& $(0.0200)$ \\
Debt & -0.0167 \\
& \\
Growth & $(0.0297)$ \\
Ranking & 0.00116 \\
& $(0.00213)$ \\
\end{tabular}




\begin{tabular}{ll}
\hline Constant & $2.027^{* * *}$ \\
& $(0.442)$ \\
\hline Time effect & Yes \\
Industry dummy & Yes \\
Observations & 901 \\
R-squared & 0.638 \\
\hline
\end{tabular}

Note: 1. Standard errors in parentheses.

2. * ** and *** mean significance at $10 \%, 5 \%$, and $1 \%$ levels, respectively, and standard errors.

\section{Robustness Check}

This study chooses the linear probability model following prior studies. This method is convenient and easier to interpret (Angrist and Pischeke, 2008). On the other hand, there is argument that the ordered probit model would be more appropriate if the number of dependent variables is limited. To confirm validity of the estimated results, we applied the ordered probit model. From the results reported in Table 8, we confirm the relationships between ESG evaluations and corporate attractiveness are similar with the results using OLS.

TABLE 8

ORDERED PROBIT MODEL REGRESSION RESULTS

\begin{tabular}{|c|c|c|c|c|c|}
\hline & $(1)$ & (2) & (3) & (4) & $(5)$ \\
\hline \multirow[t]{2}{*}{ ROA } & $0.0711 * * *$ & $0.0519 * * *$ & $0.0451 * * *$ & $0.0405 * *$ & $0.0572 * * *$ \\
\hline & $(0.0194)$ & $(0.0150)$ & $(0.0151)$ & $(0.0159)$ & $(0.0152)$ \\
\hline \multirow[t]{2}{*}{ Ln(cap) } & $-0.581 * * *$ & $-0.458 * * *$ & $-0.452 * * *$ & $-0.460 * * *$ & $-0.487 * * *$ \\
\hline & $(0.0605)$ & $(0.0454)$ & $(0.0475)$ & $(0.0484)$ & $(0.0464)$ \\
\hline \multirow[t]{2}{*}{ Growth } & -0.00684 & -0.00612 & -0.00587 & -0.00699 & -0.00744 \\
\hline & $(0.00628)$ & $(0.00504)$ & $(0.00495)$ & $(0.00513)$ & $(0.00546)$ \\
\hline \multirow[t]{2}{*}{$\mathrm{P} / \mathrm{E}$} & -0.000481 & -0.000424 & -0.00139 & -0.000977 & -0.00178 \\
\hline & $(0.00384)$ & $(0.00269)$ & $(0.00274)$ & $(0.00287)$ & $(0.00282)$ \\
\hline ESG & $\begin{array}{l}-0.00759 \\
(0.00550)\end{array}$ & & & & \\
\hline S1 & & $\begin{array}{l}-0.0104 * * \\
(0.00482)\end{array}$ & & & \\
\hline $\mathrm{S} 2$ & & & $\begin{array}{l}-0.0100 * * \\
(0.00415)\end{array}$ & & \\
\hline $\mathrm{E}$ & & & & $\begin{array}{l}-0.0118 * * * \\
(0.00403)\end{array}$ & \\
\hline $\mathrm{G}$ & & & & & $\begin{array}{l}-0.0117 * * \\
(0.00557)\end{array}$ \\
\hline Time effect & Yes & Yes & Yes & Yes & Yes \\
\hline Industry dummy & Yes & Yes & Yes & Yes & Yes \\
\hline Observations & 376 & 689 & 695 & 663 & 665 \\
\hline LogLik & -574.7 & -1082 & -1091 & -1030 & -1044 \\
\hline
\end{tabular}

Note: 1. Standard errors in parentheses.

2. *, ** and $* * *$ mean significance at $10 \%, 5 \%$, and $1 \%$ levels, respectively, and standard errors.

\section{CONCLUSION}

This study addresses the scarcity of research that examines linkage between ESG evaluation and corporate value with the focus on corporates' attractiveness for employers. The empirical results show ESG evaluation is related to firms' attractiveness as employers, suggesting that a firm's high ESG scores may 
provide a competitive advantage in attracting human talents which could provide corporate sustainable competitive advantage.

The coefficient significance of each component is different depending on the group of firms. $\mathrm{E}$ (environment) factor has significant positive impact on attractiveness for employer in larger firm group, while $\mathrm{G}$ (governance) is most relevant for smaller firm group.

The results of this study have implications for the strategies of corporate management. Improving ESG evaluation will support the organizations to appeal to potential employee and secure sustainable growth. The findings could also be useful for investors who adopt ESG factors in decision making. In the Japanese firm context, the needs to improve ESG evaluation and attract qualified talent is more critical, given diminishing supply of younger labor force and labor shortage in some industries such as information technology, construction, service and medical and welfare. Corporates can do this by signaling potential employee in advertisements that they offer a work environment conductive to ESG activities such as environmental protection, diversity, transparent corporate governance and by providing culture that reinforce individual workers' identities of social contribution.

The results of this study have policy implications. Though ESG investment has gained more support from the government and regulatory authority, the level of implementation, ESG disclosure and transparency are diverse among countries. This finding could give more incentives to the government to improve the framework of ESG investment as better disclosure will support market function and enhance ESG activities of the corporate.

Finally, we address the limitations of the study. The study covers top-tier Japanese firms for the years 2016 to 2019. An extension of the sample could explore the research perspective. Investing the link between ESG evaluation and other factors related with competitive advantage such as loyalty of employee is another agenda for research.

\section{ENDNOTES}

1. The net increase of funds which have incorporated ESG factors reached $\$ 1.3$ trillion during January to November 2020, increased by 1.5 times from the level in 2019.

2. The PRI was launched in 2006 to encourage investors to incorporate ESG issues into investment practices through six principles.

3. MSCI Inc., is an American finance company headquartered in New York City and serving as a global provider of equity, fixed income, hedge fund stock market indexes, multi-asset portfolio analysis tools and ESG related products.

4. FTSE Russell is the trading name of London Stock Exchange Group subsidiaries FTSE International Ltd. The division provides equity index, as well as other indices and ESG products.

5. Sustainalytics is a subsidiary of Morning Star that rates the sustainability of listed companies based on their environmental, social and corporate governance performance.

6. The Government Pension Investment Fund (GPIF), the largest asset owner in the world, signed PRI in 2015 and adapted Japan's Stewardship Code which encourage investors to integrate ESG factors acted as a catalyst for penetration of ESG investment in Japan.

7. As of May 2019, only $0.13 \%$ of private corporate pension funds have adapted Japan's Stewardship Code.

8. Employment brand ranking is accessible from this site https://www.careerpartners.co.jp/laboratory/employ/

9. The first dimension, environmental performance, covers the performance on environmental organization and information disclosure, environmental performance. The second dimension, human source utilization, covers the performance on utilization of diverse human resources, human rights, labor issues, employment of persons with disabilities, personnel and evaluation system, work-life balance, and wages and leave system. The third dimension, social contribution, covers the performance on social contribution business department, social contribution activity spending, community participation activities, educational/academic support activities, culture/arts/sports support activities, international exchange participation activities, great east Japan earthquake and other reconstruction support. Finally, the fourth dimension, corporate governance, covers the performance on corporate governance, legal compliance, internal control. Evaluations are carried out on a company-wide, all-industry uniform basis. 


\section{REFERENCES}

Beck, C., Frost, G., \& Jones, S. (2018). CSR disclosure and financial performance revisited: A crosscountry analysis. Australian Journal of Management, 43(4), 517-537.

Brammer, S.J., \& Pavelin, S. (2006). Corporate reputation and social performance: The importance of fit. Journal of Management Studies, 43(3), 435-455.

Cho, E., \& Tsang, A. (2020). Corporate Social Responsibility, Product Strategy, and Firm Value. AsiaPacific Journal of Financial Studies, 49(2), 272-298.

Cho, M.H. (1998). Ownership structure, investment, and the corporate value: An empirical analysis. Journal of Financial Economics, 47(1), 103-121.

Davies, J.R., Hillier, D., \& McColgan, P. (2005). Ownership structure, managerial behavior and corporate value. Journal of Corporate Finance, 11(4), 645-660.

De la Fuente Sabaté, J.M., \& de Quevedo Puente, E. (2003). Empirical analysis of the relationship between corporate reputation and financial performance: A survey of the literature. Corporate Reputation Review, 6(2), 161-177.

Deloitte, P. (2019). Mind the gaps: The 2019 Deloitte millennial survey. Retrieved September 11, 2020.

Du, S., Bhattacharya, C.B., \& Sen, S. (2010). Maximizing business returns to corporate social responsibility (CSR): The role of CSR communication. International Journal of Management Reviews, 12(1), 8-19.

El Ghoul, S., Guedhami, O., Kwok, C.C., \& Mishra, D.R. (2011). Does corporate social responsibility affect the cost of capital? Journal of Banking \& Finance, 35(9), 2388-2406.

Friede, G., Busch, T., \& Bassen, A. (2015). ESG and Financial Performance: Aggregate Evidence from more than 2000 Empirical Studies. Journal of Sustainable Finance \& Investment, 5(4), 210-233.

Gardberg, N.A., \& Fombrun, C.J. (2006). Corporate citizenship: Creating intangible assets across institutional environments. Academy of Management Review, 31(2), 329-346.

Global Sustainable Investment Alliance (GSIA). (2018). Global Sustainable Investment Review.

Government Pension Investment Fund. (2019). ESG Annual Report.

Gregory, A., Tharyan, R., \& Whittaker, J. (2014). Corporate social responsibility and firm value: Disaggregating the effects on cash flow, risk and growth. Journal of Business Ethics, 124(4), 633-657.

Hoeffler, S., \& Keller, K.L. (2002). Building brand equity through corporate societal marketing. Journal of Public Policy \& Marketing, 21(1), 78-89.

Hur, W.M., Kim, H., \& Woo, J. (2014). How CSR leads to corporate brand equity: Mediating mechanisms of corporate brand credibility and reputation. Journal of Business Ethics, 125(1), 75-86.

Ibuki, E. (2003, September). Corporate social responsibility and corporate strategy (Japanese). Chitekishisansouzou, pp. 54-71.

Institute of International Finance. (2020). Sustainable Debt Monitor.

Jo, H., \& Na, H. (2012). Does CSR reduce firm risk? Evidence from controversial industry sectors. Journal of Business Ethics, 110(4), 441-456.

Kato, Y. (2020). Environmental, Social, and Governance Factors and Their Implications for Equity Investments. ESG Investment: Opportunities and Risks for Asia, chapter 3, 49-70. Tokyo: ADBI.

Keller, K.L., \& Lehmann, D.R. (2006). Brands and branding: Research findings and future priorities. Marketing Science, 25(6), 740-759.

Margolis, J.D., \& Walsh, J.P. (2003). Misery loves companies: Rethinking social initiatives by business. Administrative Science Quarterly, 48(2), 268-305.

McKinsey \& Company. (2020). The ESG premium: New perspectives on value and performance.

Melo, T., \& Garrido-Morgado, A. (2012). Corporate reputation: A combination of social responsibility and industry. Corporate Social Responsibility and Environmental Management, 19(1), 11-31.

Mosca, F., \& Civera, C. (2017). The Evolution of CSR: An Integrated Approach, Symphonya. Emerging Issues in Management (symphonya.unimib.it), 1, 16-35. 
Oikonomou, I., Brooks, C., \& Pavelin, S. (2012). The impact of corporate social performance on financial risk and utility: A longitudinal analysis. Financial Management, 41(2), 483-515.

Roberts, P.W., \& Dowling, G.R. (2002). Corporate reputation and sustained superior financial performance. Strategic Management Journal, 23(12), 1077-1093.

Servaes, H., \& Tamayo, A. (2013). The impact of corporate social responsibility on firm value: The role of customer awareness. Management Science, 59(5), 1045-1061.

Su, R., Liu, C., \& Teng, W. (2020). The heterogeneous effects of CSR dimensions on financial performance-A new approach for CSR measurement. Journal of Business Economics and Management, 21(4), 987-1009.

Suto, M., \& Takehara, H. (2016). The link between corporate social performance and financial performance: Empirical evidence from Japanese firms. International Journal of Corporate Strategy and Social Responsibility, 1(1), 4-25.

Suto, M., \& Takehara, H. (2018). Corporate Social Responsibility and Corporate Finance in Japan. Japan: Springer.

Turban, D.B., \& Greening, D.W. (1996). Corporate Social Performance and Organizational Attractiveness to Prospective Employees. Academy of Management Journal, 40(3), 658-672.

Van Beurden, P., \& Gössling, T. (2008). The worth of values-a literature review on the relation between corporate social and financial performance. Journal of Business Ethics, 82(2), 407.

Waddock, S.A., \& Graves, S.B. (1997). The corporate social performance-financial performance link. Strategic Management Journal, 18(4), 303-319.

Yuyama, T. (2020). ESG Investment and Performance (Japanese). Japan: Kinzai Press.

Yuyama, T., Shirasu, Y., \& Soichiro, M. (2019). ESG Disclosure Score and Investment Performance (Japanese). Securities Analysts Journal, 57(10), 72-83.

Zhao, C., Guo, Y., Yuan, J., Wu, M., Li, D., Zhou, Y., \& Kang, J. (2018). ESG and corporate financial performance: Empirical evidence from China's listed power generation companies. Sustainability, 10(8), 2607. 